\title{
Waarom de islam en de moslimgemeenschap onmisbare bondgenoten zijn bij de bestrijding van terrorisme
}

\author{
Tom Zwart
}

\section{Inleiding}

Het terrorisme dat in naam van de islam wordt gepleegd, vormt een grote bedreiging voor onze samenleving. In Nederland wordt dit probleem vooral bestreden met behulp van door de overheid ontwikkelde maatregelen, ${ }^{1}$ zoals strafwetgeving, het tegengaan van radicalisering, het domesticeren van de islam, en het verstoren van problematisch gedrag. ${ }^{2}$ Strafvorderlijke interventies vinden steeds vroeger in de keten plaats, ${ }^{3}$ waardoor het werk van politie en justitie en dat van de inlichtingen- en veiligheiddiensten inniger met elkaar verweven raken. Steeds vaker doen ambtsberichten van de Algemene Inlichtingen- en Veiligheidsdienst (AIVD) dienst als startinformatie voor een strafrechtelijk onderzoek naar terrorisme en gelden ze in dat onderzoek als bewijs. ${ }^{4}$ Daarnaast is een belangrijke rol weggelegd voor het concept van 'radicalisering', aan de hand waarvan zou kunnen worden voorspeld wie zich eventueel aan geweld schuldig zal gaan maken. ${ }^{5}$ Onderzoekers

* De auteur is Nisrine Zibouh, Hafsa Zamour en Sousan Bouzidi, die als onderzoekers verbonden zijn aan het Cross-cultural Human Rights Centre, zeer erkentelijk voor hun deskundige input en de interessante discussies.

1 Ministerie van Veiligheid en Justitie, Nationaal Coördinator Terrorismebestrijding en Veiligheid en Ministerie van Sociale Zaken en Werkgelegenheid, Actieprogramma Integrale Aanpak Jihadisme: Overzicht Maatregelen en Acties, Den Haag 2014.

2 M. van der Woude, Wetgeving in een Veiligheidscultuur: Totstandkoming van Antiterrorismewetgeving in Nederland bezien vanuit Maatschappelijke en (Rechts)Politieke Context, Den Haag 2010; J.R. Bowen, 'Does French Islam Have Borders? Dilemmas of Domestication in a Global Religious Field', American Anthropologist 2004-1, p. 43-55; T. Sunnier, 'Domesticating Islam: Exploring Academic Knowledge Production on Islam and Muslims in European Societies', Ethnic and Racial Studies 2014-6, p. 1138-1155; T. Zwart, 'Bestuurlijk Stalken en de Rechtstatelijkheidstoets van Minister Blok', www.montesquieu-instituut.nl/id/vkxad1e8k0u8/nieuws/bestuurlijk_stalken_ en_de.

3 M.F.H. Hirsch Ballin, Anticipative Criminal Investigation: Theory and Counterterrorism Practice in The Netherlands and the United States, Den Haag 2012.

4 F. Krips, Over de Bruikbaarheid van AIVD-informatie in Strafzaken (Preadvies voor de Vereniging voor de Vergelijkende Studie van het Recht van België en Nederland), Den Haag 2009.

5 BVD, Jaarverslag 2001, Den Haag 2002, p. 30, www.aivd.nl/documenten/jaarverslagen/ 2002/05/28/jaarverslag-bvd-2001; AIVD, Jaarverslag 2003, Den Haag 2004, p. 33-43, www.aivd.nl/documenten/jaarverslagen/2004/04/27/jaarverslag-aivd-2003; M. Slootman \& J. Tillie, Processen van Radicalisering: Waarom Sommige Amsterdammers Radicaal Worden, Instituut voor Migratie en Etnische Studies, Universiteit van Amsterdam 2006; A.J. Gielen, Radicalisering en Identiteit: Radicale Rechtse en Moslim Jongeren Vergeleken, Amsterdam 2008; K. van den Bos, Why People Radicalise: How Unfairness Judgments Are Used to Fuel Radical Beliefs, Extremist Behaviors, and Terrorism, Oxford 2018. 
als Githens-Mazer en Kundnani hebben inmiddels aangetoond dat op de wetenschappelijke validiteit van dat radicaliseringconcept het nodige valt af te dingen en daarom wordt het in deze bijdrage niet gebruikt. ${ }^{6}$

Het is zeer de vraag of deze door de overheid gestuurde aanpak werkt. ${ }^{7}$ Diverse commentatoren hebben er namelijk op gewezen dat deze niet effectief is. ${ }^{8}$ Daarom ligt het voor de hand om niet exclusief aan deze door de overheid geregisseerde benadering vast te houden, maar om ook naar mogelijke alternatieven te zoeken. ${ }^{9}$ Aan dit artikel ligt de veronderstelling ten grondslag dat het goed zou zijn om aan de islam en de moslimgemeenschap de hoofdrol toe te kennen bij de bestrijding van het terrorisme.

In paragraaf 2 zal zichtbaar worden gemaakt dat de islam een bijdrage kan leven aan de oplossing van het terrorismevraagstuk omdat het verweven is met de oorzaken daarvan. In paragraaf 3 zal worden ingegaan op het theologisch gedachtegoed van de aanhangers van het terrorisme, die in dit artikel in navolging van Adroui worden aangeduid als 'militante jihadisten': de aanhangers van een gewelddadige, transnationale interpretatie van de jihad die de beweerdelijke vijanden van de islam bevechten en die streven naar een terugkeer naar de begintijd van de islam. ${ }^{10}$ In paragraaf 4 worden de mogelijkheden die de islam biedt voor de proactieve oplossing van het terrorismevraagstuk geschetst, en in paragraaf 5 komen de correctieve opties aan bod. In paragraaf 6 worden bij wijze van aanbeveling de contouren van een pilot geschetst. Paragraaf 7 bevat enkele conclusies. Zoals in paragraaf 2.2 nader zal worden uitgewerkt, is in deze bijdrage gebruikgemaakt van de inzichten die binnen de moslimgemeenschap bestaan over dit onderwerp. Daarnaast is de wetenschappelijke literatuur geraadpleegd. Daarbij

6 J. Githens-Mazer \& R. Lambert, "Why Conventional Wisdom on Radicalization Fails: The Persistence of a Failed Discourse', International Affairs 2010-4, p. 889-901; A. Kundnani, 'Radicalisation: The Journey of a Concept', Race and Class 2012-2, p. 3-25; Ch. Heath-Kelly, 'CounterTerrorism and the Counterfactual: Producing the "Radicalisation" Discourse and the UK PREVENT Strategy', British Journal of Politics and International Relations 2013-15, p. 394-415; A. Kundnani, The Muslims Are Coming! Islamophobia, Extremism, and the Domestic War on Terror, Londen 2014; N. Fadil, M. de Koning \& F. Regazzi (red.), Radicalization in Belgium and The Netherlands: Critical Perspectives on Violence and Security, Bloomsbury 2019.

7 Ministerie van Veiligheid en Justitie, Onderzoeksrapport Artikel 36.2 Beleidsdoorlichting Nationale Veiligheid Terrorismebestrijding, Den Haag 2017, p. 45-49.

8 T. Legrand \& M. Lister, 'From Precaution to Prejudice: Mistakes in Counter-terrorism', in: A. Kruck, K. Opperman \& A. Spencer (red.), Political Mistakes and Policy Failures in International Relations, Cham 2018, p. 33-53; W.A. Davies, 'Counterterrorism Effectiveness to Jihadists in Western Europe and the United States: We Are Losing the War on Terror', Studies in Conflict \& Terrorism 2018-4, p. 281-296; E.W. Goepner, 'Measuring the Effectiveness of America's War on Terror', Parameters 2016-1, p. 107-120.

9 V. Dodd, 'Counter-terror Chief Says Policing Alone Cannot Beat Extremism, Neil Basu Calls for Sociologists and Criminologists to Help Tackle Terrorism in UK', The Guardian 6 augustus 2019, www.theguardian.com/uk-news/2019/aug/06/counter-terrorism-chief-calls-for-greater-socialinclusion.

10 M.A. Adroui, 'Salafism, Jihadism, and Radicalisation: Between a Common Doctrinal Heritage and the Logics of Empowerment', in: S. Pektras \& J. Leman (red.), Militant Jihadism, Today and Tomorrow, Leuven 2019, p. 19-39, i.h.b. p. 19. 
ligt de nadruk op het internationale discours, omdat dit onderwerp daarin meer aandacht krijgt dan in de Nederlandse discussie.

\section{Een alternatieve aanpak van terrorisme}

\subsection{Sociale in plaats van formele instituties: de islam en de moslimgemeenschap als bondgenoten tegen terrorisme}

Bij de bestrijding van terrorisme ligt de nadruk momenteel op door de overheid geïnitieerde maatregelen, oftewel formele instituties, maar sociale instituties zouden als alternatief kunnen dienen. ${ }^{11}$ Sociale instituties zijn gedragspatronen die door leden van een bepaalde gemeenschap in acht worden genomen en waaraan zij zich gebonden achten, niet omdat die door de overheid worden gesanctioneerd, maar omdat die worden gedicteerd door hun gemeenschappelijke culturele waarden. ${ }^{12}$ Sociale instituties normeren het gedrag op essentiële terreinen van het maatschappelijk leven, zoals familiebetrekkingen, onderwijs, bestuur, economie en religie. Daarom is het van belang te bezien in hoeverre de islam kan worden ingezet bij de voorkoming en bestrijding van terrorisme.

Hoewel terroristen de islam inroepen als rationale voor hun daden, blijft deze theologische dimensie onderbelicht in de terrorismestudies en het -beleid. ${ }^{13}$ De belangrijkste reden daarvoor is dat zowel degenen die ontkennen dat er een verband bestaat tussen islam en terrorisme als degenen die zo'n verband wel aannemen, geen rol weggelegd zien voor de islam als remedie.

Enerzijds ontkennen sommige commentatoren, zoals Said, Halliday en Esposito, dat er een oorzakelijke relatie zou zijn tussen de islam en terrorisme, zelfs nu terroristen dat verband wel leggen. ${ }^{14}$ Volgens hen bestaat er weliswaar een gewelddadige ideologie, het zogenoemde 'islamisme', maar die houdt geen verband met de islam als religie. Islamisme komt voort uit economische omstandigheden, kolonialisme en westers imperialisme. De beste manier om dit islamistische terrorisme te bestrijden is volgens de leden van deze school een andere, meer verwelkomende opstelling van westerse overheden jegens de islamitische wereld. Voor de islam als geloof is daarbij geen rol weggelegd.

11 B. de Graaf, 'Terrorisme- en Radicaliseringsstudies', Justitiële Verkenningen 2017-3, p. 8-29; J.D. Cohen, 'The Next Generation of Government CVE Strategies at Home: Expanding Opportunities for Intervention', Annals of the American Academy of Political and Social Science 2016-668, p. 118-128; G. Selim, 'Approaches for Countering Violent Extremism at Home and Abroad', Annals of the American Academy of Political and Social Science 2016-668, p. 95-101; L. Macnair \& R. Frank, 'Voices against Extremism: A Case Study of a Community-Based Counter-Narrative', Journal for Deradicalization 2017, p. 147-174, i.h.b. p. 152.

12 T. Parsons, 'Prolegomena to a Theory of Social Institutions', American Sociological Review 1990-3, p. 319-333; J.S. Coleman, 'Commentary: Social Institutions and Social Theory', American Sociological Review 1990-3, p. 33-339.

13 Uitzonderingen zijn L.L. Dawson, 'Debating the Role of Religion in the Motivation of Religious Terrorism', Nordic Journal of Religion and Society 2018-2, p. 98-117 en M. Croes, 'De Relatie tussen Islam en Terrorisme: Een Empirische Benadering', Justitiële Verkenningen 2017-3, p. 68-84.

14 M. Sulaiman, 'Orientalism and Anti-Orientalism: Epistemogical Approaches to Islam and Violence', in: F. Mansouri \& Z. Keskin (red.), Contesting the Theological Foundations of Islamism and Violent Extremism, Palgrave Macmillan 2019, p. 75-95. 
Anderzijds zijn er diegenen, onder wie Lewis, Pipes en Karsh, die de islam als een gewelddadige godsdienst beschouwen, waarvan terrorisme een logisch uitvloeisel is. Maar ook deze commentatoren kennen geen rol toe aan de islam bij de oplossing ervan. ${ }^{15}$ In hun ogen is de beste remedie om de islam van zijn inherente gewelddadige karakter te ontdoen, deze in te passen in het liberaal-modernistische kader. Het radicaliseringconcept - iedere moslim kan vanwege het inherent gewelddadige karakter van de islam uitgroeien tot een terrorist - is een uitvloeisel van deze benadering.

Daarnaast spelen nog enkele andere factoren een rol. Zo hebben onderzoekers vaak een blinde vlek voor religie omdat dat verschijnsel in de seculiere omgeving waarvan zij deel uitmaken geen rol van betekenis speelt. ${ }^{16}$ In de woorden van Graeme Wood: 'if religious ideology doesn't matter much in Washington or Berlin, surely it must be equally irrelevant in Raqqa or Mosul'. ${ }^{17}$ Secularisme fungeert in dit verband voor onderzoekers als een epistemologische blokkade. ${ }^{18}$ Shakman Hurd heeft aangetoond dat deze seculiere blikvernauwing een belemmering oplevert voor het verrichten van valide wetenschappelijk onderzoek. ${ }^{19} \mathrm{Als}$ gevolg van deze seculiere perceptie laten onderzoekers de religieuze verklaringen van militante jihadisten buiten beschouwing en concentreren zij zich in plaats daarvan op politieke, sociale en economische factoren. ${ }^{20}$

Bovendien ontberen terrorisme-experts en beleidsmakers vaak de noodzakelijke kennis van de islamitische theologie. ${ }^{21}$ Om de islam goed te begrijpen zijn een grondige theologische studie en beheersing van het Arabisch noodzakelijk. Onderzoekers en beleidsmakers die aan die vereisten voldoen, zijn dun gezaaid. Als gevolg daarvan baseren beleidsmakers en commentatoren zich nogal eens op een incomplete voorstelling van de islam die wordt beïnvloed door seculiere en christelijke schema's. ${ }^{22}$

Ten slotte valt het betrekken van de islam bij het beleid volgens commentatoren moeilijk te rijmen met de godsdienstvrijheid en de scheiding van kerk en staat. ${ }^{23}$

16 R. Lévy, 'Does Jihadist Terrorism Have Religious Foundations? Jihadist Attacks and Academic Controversies in France (2012-2017)', Revista de Conflito e Controle Social 2019-12, p. 217-238, i.h.b. p. 221-222; D. Crouzet \& J.M. Le Gall, Au Péril des Guerres de Religion: Réflections de Deux Historiens sur Notre Temps, Parijs 2015; J. Birnbaum, Un Silence Religieux: La Gauche Face a Dihadisme, Parijs 2016; zie ook Gutkowski, 'The British Secular Habitus and the War on Terror', Journal of Contemporary Religion 2012-1, p. 87-103.

17 G. Wood, 'What ISIS Really Wants', The Atlantic, maart 2015, p. 82.

18 G. Bachelard, La Formation de l'Esprit Scientifique, Parijs 1934, p. 16-26.

19 E. Shakman Hurd, The Politics of Secularism in International Relations, Princeton 2008.

20 M.R. Habeck, Knowing the Enemy: Jihadist and the War on Terror, New Haven 2006, p. 7.

21 D. Koehler, Understanding Deradicalization, Methods, Tools and Programs for Countering Violent Extremism, Abingdon 2017, p. 83, 118 en 201-207.

22 Gutkowski 2012, p. 97-98; M.L. Browers, 'The Secular Bias in Ideology Studies and the Case of Islamism', Journal of Political Ideologies 2005-1, p. 75-93. 
Dat maakt het lastig om theologische inzichten bij de beleidsvorming te betrekken. ${ }^{24}$

Zoals in paragraaf 3 zal worden beschreven, staat niettemin vast dat militante jihadisten zich niet alleen beroepen op maar zich vaak ook laten inspireren door de islam. ${ }^{25} \mathrm{Om}$ het terrorismevraagstuk op te lossen is het daarom van belang om te bestuderen wat de militante jihadisten te zeggen hebben en hoe zij te werk gaan. ${ }^{26}$

Dit betekent zeker niet dat de islam in algemene zin verantwoordelijk moet worden gehouden voor terrorisme en dat alle moslims op één hoop moeten worden gegooid. ${ }^{27}$ Integendeel, het is juist zeer relevant dat het overgrote deel van de moslims en islamgeleerden het militante jihadisme beschouwt als een dwaalleer en zelfs als een karikatuur van de islam die gebaseerd is op een onjuiste en oneigenlijke interpretatie van de bronnen. ${ }^{28}$ Dit betekent dat de islamgeleerden en de leden van de moslimgemeenschap die op theologische gronden bezwaar maken tegen het militante jihadisme, cruciale bondgenoten zijn in de strijd tegen het terrorisme. Door de theologische opvattingen van de militante jihadisten ter discussie te stellen en te corrigeren kan het terrorisme dan ook worden teruggedrongen.

\subsection{De keuze voor een gemeenschap-engagerende aanpak}

In de antropologie worden twee methoden gebruikt om het gedrag van gemeenschappen te duiden, die zijn geïdentificeerd door Kenneth. ${ }^{29}$ De onderzoeker kan een etische benadering volgen, die het doen en laten van de gemeenschap van buitenaf analyseert met behulp van externe criteria en daarin systeem brengt met behulp van een generieke matrix. Een nadeel van deze benadering is dat de werkelijkheid vervormd kan worden door de eigen cognitieve frames van de onderzoeker. Het alternatief is een emische benadering, die de manier van doen van de gemeenschap in kaart probeert te brengen met behulp van een insidersperspectief: daarbij wordt zo veel mogelijk uitgegaan van de cognitieve schema's van de leden van de gemeenschap zelf. Zo'n benadering stelt de gemeenschap in staat om haar eigen script te schrijven in plaats van dat van anderen uit te voeren. ${ }^{30}$ Een nadeel is dat emisch onderzoek alleen kan worden verricht door onderzoekers die toegang hebben tot deze insiderskennis.

24 Wel hebben overheden geprobeerd om hiertoe ruimte te vinden; zie voor de pogingen van de gemeente Amsterdam: F. Vermeulen, 'Suspect Communities - Targeting Violent Extremism at the Local Level: Policies of Engagement in Amsterdam, Berlin and London', Terrorism and Political Violence 2014-2, p. 286-306, i.h.b. p. 301.

25 Wood 2015, p. 17; Habeck 2006, p. 3.

26 Habeck 2006, p. 5, 15.

27 Habeck 2006, p. 3.

28 S. Pektras, 'Prospects of Counter-Theology against Militant Jihadism', in: S. Pektras \& J. Leman (red.), Militant Jihadism, Today and Tomorrow, Leuven 2019, p. 187-214.

29 K.L. Pike, Language in Relation to a Unified Theory of the Structure of Human Behavior (2de druk), Den Haag 1967, p. 37-39.

30 E.F. Isin, 'Theorizing Acts of Citizenship', in: E.F. Isin \& G.M. Nielsen (red.), Acts of Citizenship, Londen 2008, p. 15-43, 38. 
Door zogenoemd gemeenschap-engagerend onderzoek te verrichten kan het emische perspectief voorop worden gesteld. ${ }^{31}$ Gemeenschap-engagerend onderzoek kent de gemeenschap waarop het onderzoek betrekking heeft een sleutelrol toe bij het opstellen van de onderzoeksagenda en betrekt deze intensief bij het uitstippelen van de koers en bij de uitvoering van het onderzoek. Veel relevante kennis en expertise wordt aangeleverd door actoren binnen die gemeenschap. Om succesvol gemeenschap-engagerend onderzoek te kunnen doen moeten de onderzoekers een vertrouwensband hebben met de gemeenschap. Daarbij gaat het niet om een incidenteel contact om ad hoc een project te kunnen uitvoeren, maar om langdurige bestendige relaties die soms gepaard gaan met het verrichten van onderzoek. ${ }^{32}$

Het onderzoek dat wordt verricht naar terrorisme dat in naam van de islam wordt gepleegd, is thans vooral etisch van aard. Daarom is ten behoeve van deze bijdrage in plaats daarvan een emisch perspectief gekozen. ${ }^{33} \mathrm{Om}$ in kaart te brengen hoe de Nederlandse moslimgemeenschap omgaat met religieus geïnspireerd terrorisme en welke oplossingen daartoe binnen de gemeenschap voorhanden zijn, is een gemeenschap-engagerend onderzoek uitgevoerd. Dat bood de gelegenheid om gebruik te maken van de expertise, inzichten, ervaring en het gezag op het terrein van de islam die in de moslimgemeenschap aanwezig zijn. Op deze manier maakt de gemeenschap bovendien zichtbaar dat zij terrorisme zeer serieus neemt en zich als probleemeigenaar beschouwt. Aangezien terroristen niet kunnen slagen zonder steun vanuit de bevolking, neemt de gemeenschap op deze wijze ook de benodigde zuurstof weg. ${ }^{34}$ Door de betrokkenheid van de gemeenschap zal ook de legitimiteit van het antiterrorismebeleid toenemen. ${ }^{35}$

Dit artikel is naast de relevante literatuur dan ook gebaseerd op de uitkomsten van focusgroepen waaraan islamgeleerden, moskeebestuurders, imams en moslimjongeren hebben deelgenomen. De uitkomsten van die focusgroepen zijn gevalideerd tijdens bijeenkomsten in moskeeën, bij religieuze verenigingen en tijdens enkele groepssessies met ongeveer 150 moslimjongeren.

\subsection{De noodzaak van zowel een correctieve als een proactieve benadering}

Veel antiterrorismemaatregelen zijn gericht op moslimjongeren die zich al op het extremistische pad hebben begeven of op het punt staan dat te doen. Dergelijke acties zijn ontegenzeggelijk belangrijk, maar hun insteek is te beperkt. Dat kan

31 In de Anglo-Amerikaanse literatuur wordt dit type onderzoek aangeduid als community-engaged research (CEnR) of community-based participatory research (CBPR); zie B.A. Israel e.a. (red.), Methods for Community-Based Participatory Research for Health, San Francisco 2013; M.A. Post e.a. (red.), Publicly Engaged Scholars, Next Generation Engagement and the Future of Higher Education, Sterling 2016.

32 P.A. McElfish e.a., 'Best Practices for Community-Engaged Research with Pacific Islander Communities in the US and USAPI: A Scoping Review', Journal of Health Care for the Poor and Underserved 2019-4, p. 1302-1330, i.h.b. p. 1311-1312.

33 Het belang daarvan wordt benadrukt door D. Figueira, Salafi Jihadi Discourse of Sunni Islam in the 21st Century, The Discourse of Abu Muhammad al-Maqdisi and Anwar al-Awlaki, Bloomington 2011.

34 A. Cherney \& J. Hartley, 'Community Engagement to Tackle Terrorism and Violent Extremism: Challenges, Tensions and Pitfalls', Policing and Society 2017-27, p. 750-763, 751-752. 
worden aangetoond met behulp van de metafoor van het trappenhuis die Fathali Moghaddam gebruikt om het proces dat leidt tot terrorisme te beschrijven. ${ }^{36} \mathrm{Op}$ de begane grond ervaart een grote groep personen onrechtvaardigheid en achterstand. Sommige leden van die groep gaan op zoek naar oplossingen en komen zo op de eerste verdieping terecht. Een deel van deze personen begeeft zich naar de tweede verdieping en zo verder. Uiteindelijk komt een klein deel op de vijfde verdieping terecht, waar zij betrokken raken in terroristische acties.

Moghaddam geeft terecht aan dat het huidige terrorismebeleid vrijwel uitsluitend gericht is op degenen die zich op de bovenste verdieping bevinden, maar voor het bereiken van langetermijnoplossingen is het belangrijk om de aandacht juist ook te richten op de begane grond. Dat vraagt om een aanpak die voorkomt dat extremistische aspiraties überhaupt de kop opsteken of - als dat onverhoopt niet zou lukken - die ervoor zorgt dat ze in elk geval in een zo vroeg mogelijk stadium worden weggenomen. Het is veel effectiever om personen aan te spreken die nog een onbeschreven blad zijn dan om personen die het extremisme al hebben omarmt terug te brengen naar de maatschappij. Daarom wordt in deze bijdrage niet alleen ingegaan op correctief ingrijpen (paragraaf 5), maar ook op proactief beleid (paragraaf 4).

\section{De theologie van het militante jihadisme}

De organisaties die oproepen tot het plegen van aanslagen, zoals Al Qaida en IS, hangen een gewelddadige leer aan die elementen ontleent aan zowel het salafisme als het radicale islamistische gedachtegoed van twintigste-eeuwse denkers zoals Sayyid Qutb en Abu Muhammad al-Maqdisi. Deze leer vindt zijn oorsprong in de benadering van de beweging Jamaat al-Muslimin, die ook wel wordt aangeduid als Jamaat al-Takfir w'al-Hijrah. ${ }^{37}$

Het salafisme is een pluriforme hervormingsbeweging die gericht is op herstellen van de islam in zijn zuivere vorm. ${ }^{38}$ De methode die daarvoor wordt gebruikt, is het volgen van de Koran en de traditie van de Profeet op de manier waarop salafisten interpreteren dat de eerste drie generaties moslims die begrepen en praktiseerden. ${ }^{39}$ Aangezien zij zich bij uitstek richten op de letterlijke tekst van de

36 F.M. Moghaddam, 'The Staircase to Terrorism, A Psychological Exploration', American Psychologist 2005-2, p. 161-169.

37 'Jamaat al-Takfir w'al-Hijrah', in: J.L. Esposito (red.), The Oxford Dictionary of Islam, Oxford, 2003; J.B. Cozzens, 'Al-Takfir w'al Hijrah: Unpacking an Enigma', Studies in Conflict \& Terrorism 2009-6, p. 489-510.

38 M. de Koning, Zoeken naar een Zuivere Islam: Geloofsbeleving en Identitieitsvorming van Jonge Marokkaans-Nederlandse Moslims, Amsterdam 2008; I. Roex, Leven als de Profeet in Nederland: Over de Salafi-Beweging en Democratie, Amsterdam 2013; F. Geelhoed, Striving for Allah. Purification and Resistance among Fundamentalist Muslims in the Netherlands, Den Haag 2014; J. Wagemakers, Salafism in Jordan: Political Islam in a Quietist Community, Cambridge 2016; H. Lauzière, The Making of Salafism, Islamic Reform in the Twentieth Century, New York 2016.

39 https://islamqa.info/en/answers/125476/the-true-salafis-are-the-followers-of-the-path-of-theprophet-blessings-and-peace-of-allah-be-upon-him-and-his-companions. 
Koran en de overleveringen van de Profeet, de soenna, nemen zij recentere interpretaties van deze bronnen niet voor zoete koek aan. ${ }^{40}$

Twintigste-eeuwse islamistische theoretici gebruiken theologische concepten als standaard voor de beoordeling van de staatkundige situatie. Zij richten hun pijlen daarbij vooral op de corrupte niet-islamitische regimes in moslimlanden en op westerse landen, in het bijzonder de Verenigde Staten, die dit soort regimes in het zadel houden. Zo kwam Sayyid Qutb tot de conclusie dat het toenmalige Egyptische bewind zich schuldig maakte aan ongeloof omdat het opereerde op basis van door mensen geschapen wetgeving in plaats van de sharia. Als gevolg daarvan hadden de gelovigen het recht om het bewind met alle beschikbare middelen in het kader van de jihad te bestrijden. ${ }^{41}$ Al-Maqdisi maakte vooral bezwaar tegen de nauwe banden die landen als Saoedi-Arabië onderhouden met de VS. ${ }^{42}$ In tegenstelling tot de salafisten zijn deze islamistische denkers niet zo trouw aan de basisteksten en de traditie en gaan zij daarmee creatief om.

De leden van de op deze mix van opvattingen gebaseerde stroming staan een indringende beleving van de islam voor. ${ }^{43} \mathrm{Zij}$ zijn doorgaans vol zelfvertrouwen en zij brengen hun radicale standpunten over de islam met overtuiging onder de aandacht. Zij beschouwen zichzelf als de voorhoede van de islam. ${ }^{44}$ De door Meijers gemaakte vergelijking met het leninisme is dan ook zeer treffend. ${ }^{45}$

Binnen de islamitische geloofsleer staat de tawhid, die het monotheïsme en de almacht van God tot uitdrukking brengt, centraal. De interpretatie van de tawhid die militante jihadisten erop nahouden, wijkt sterk af van die van andere moslims. Zij vatten deze op als een gebod om het geloof werkelijk in de praktijk te brengen en in daden om te zetten. Op grond van deze benadering maakt een gelovige die nalaat haar of zijn geloof in de praktijk te brengen zich schuldig aan ongeloof. ${ }^{46}$ Hierdoor wordt het streven van het salafisme om de zuiverheid van de islam te herstellen en te bewaren, door militante jihadisten aangescherpt tot een lakmoesproef om 'goede' van 'slechte' moslims te onderscheiden.

Ook de interpretatie die militante jihadisten erop nahouden van het concept alwala' wal bara, dat letterlijk 'loyaliteit en afwijzing' betekent, verschilt sterk van de opvatting van andere moslims. Volgens de gangbare interpretatie van dit concept dienen moslims God, de Profeet en de medegelovigen lief te hebben en afstand te bewaren tot iedereen die God, de Profeet en de gelovigen afwijst. ${ }^{47}$ Militante jihadisten vatten al-wala' wal bara op in samenhang met tawhid: moslims zijn loyaliteit verschuldigd aan God, de Profeet en andere moslims, althans

40 M. Taqi Usmani, The Legal Status of Following a Madhab, Karachi 2007.

41 S. Qutb, Milestones, New Delhi 2002.

42 J. Wagemakers, A Quietist Jihadi: The Ideology and Influence of Abu Muhammad al-Maqdisi, Cambridge 2012.

43 S. Maher, Salafi-Jihadism, The History of an Idea, Londen 2016: Habeck 2006.

44 S. Qutb, This Religion of Islam, New Dehli 1974.

45 R. Meijer, 'Introduction', in: R. Meijer (red), Global Salafism: Islam's New Religious Movement, Londen 2009, p. 25; zie Habeck 2006, p. 143.

46 D. Lav, Radical Islam and the Revival of Medieval Theology, Cambridge 2012.

47 M. Bin Ali, The Roots of Religious Extremism: Understanding the Salafi Doctrine of Al-Wala' wal Bara', Londen 2016. 
voor zover ze 'goede moslims' zijn. Contact met ongelovigen, de 'slechte moslims' daaronder begrepen, en hun cultuur en gebruiken moet daarentegen resoluut worden afgewezen. Deelname aan verkiezingen en het democratische besluitvormingsproces moet worden afgekeurd. Militante jihadisten vatten al-wala' wal bara dan ook op als een aansporing om ongelovigen te haten. ${ }^{48}$

Volgens militante jihadisten vereist het in de praktijk brengen van de islam ook de deelname aan de jihad in de zin van gewapende strijd. Volgens Abdullah Azzam, een toonaangevende spirituele leider binnen het militante jihadisme, is deelname aan de jihad zelfs de enige mogelijkheid om het geloof in de eenheid van God te tonen. Moslims die nalaten om hun overtuiging op deze manier tot uitdrukking te brengen verzaken hun religieuze plichten. ${ }^{49}$

Volgens de islam is het moslims die in eigen land door een externe vijand worden aangevallen, toegestaan zich te verdedigen in de vorm van jihad. Wie wil uitreizen om in een ander land aan de jihad deel te nemen, heeft daarvoor echter toestemming van een gezagsdrager, zoals een amir, nodig. Abdullah Azzam betwistte de noodzaak van die toestemming, ${ }^{50}$ en zijn stelling dat een niet-geautoriseerde jihad in overeenstemming is met de islam geniet onder militante jihadisten brede steun. Hierdoor is de deur opengezet naar de 'decentralisatie' van de jihad, waartoe het initiatief ook kan worden genomen door niet-statelijke actoren zoals Al Qaida en zelfs door 'lone wolves'.

De jihad is volgens de islam een vorm van zelfverdediging, maar militante jihadistische denkers hebben die notie naar plaats en tijd opgerekt. Zij beschouwen de regimes in veel moslimlanden als corrupt, onderdrukkend en decadent. Aangezien leiders die hun burgers onderdrukken en die zich opstellen als tirannen in hun ogen niet in overeenstemming met de sharia regeren, moeten deze in het kader van takfir als ongelovigen worden beschouwd die zich buiten de islam plaatsen. ${ }^{51}$ Om die reden is het gerechtvaardigd om tegen hen in opstand te komen. Degenen die dit soort heersers steunen, moeten eveneens als ongelovigen worden beschouwd. Daarom is het ook toegestaan om ambtenaren aan te vallen, zelfs als zij moslims zijn. Naar de mening van militante jihadisten is het verval van dit soort regimes in moslimlanden het gevolg van een westerse samenzwering. Daarom mag in hun visie ook tegen die westerse landen als 'verre vijand' een jihad worden gevoerd. Jihad heeft ook een preventieve dimensie gekregen: zelfs als geen sprake is van een invasie, is deze toch gerechtvaardigd in geval van permanente dreiging.

48 A. Al-Zawahiri, 'Loyalty and Enmity', in: R. Ibrahim (red.), The Al Qaeda Reader, New York 2007, p. 66-115.

49 A. Azzam, The Tawhid of Action, www.emaanlibrary.com/book/tawheed-of-action-abdullahazzam/.

50 A. Azzam, Defence of the Muslim Lands, https://english.religion.info/2002/02/01/documentdefence-of-the-muslim-lands/.

51 Maher 2016, p. 90-99; J. Nedza, Takfir im militanten Salafismus: Der Staat als Feind, Leiden 2020. 
Volgens het islamitische recht moeten de levens van non-combattanten tijdens de strijd worden gespaard en beschermd. ${ }^{52}$ Maar de militante jihadisten gaan ervan uit dat niet alleen aanvallen op de leiders, zoals politici, maar ook op burgers gerechtvaardigd zijn. Al Qaida in het bijzonder houdt burgers in het Westen mede verantwoordelijk voor de vijandige houding van hun regeringen jegens moslimlanden: zij hebben nagelaten om hun regeringen via het democratische proces op andere gedachten te brengen en ze financieren de tegen de islam gerichte daden door het betalen van belastingen. ${ }^{53}$ Bij aanvallen die door militante jihadisten worden uitgevoerd, worden vaak ook moslims gedood of verwond. Die slachtoffers worden als 'nevenschade' beschouwd van aanvallen op legitieme doelen.

\section{Een proactieve benadering}

\subsection{Social engineering met behulp van de receptorbenadering}

De leiders van organisaties als IS en Al Qaida en de theologen die hen ondersteunen zijn gepokt en gemazeld in de islamitische geloofsleer. Maar uit onderzoek blijkt dat de jongeren die door de ronselaars voor de jihad worden gerekruteerd, vaak slechts een zeer beperkte kennis hebben van de islam. ${ }^{54}$ Het bestaan van deze onwetendheidparadox werd al door Wiktorowicz geconstateerd in zijn pionierende onderzoek. Daaruit bleek dat juist novieten die nauwelijks of geen kennis hebben van de islam zich aansluiten bij terroristische organisaties. ${ }^{55}$ Dat onderzoek is recentelijk gevalideerd. ${ }^{56}$

Intuïtief komt door deze onwetendheid van de rekruten de grondslag te vervallen onder de veronderstelling dat islam een rol speelt bij het terrorisme dat in zijn naam wordt gepleegd. Dit standpunt wordt bijvoorbeeld ingenomen door Mehdi Hasan. ${ }^{57}$ In werkelijkheid liggen de zaken echter gecompliceerder. Het is waar dat de islam deze jongeren niet aanzet tot deelname aan de militante jihad, maar deze

52 A. van Engeland-Nourai, 'The Challenge of Fragmentation of International Humanitarian Law regarding the Protection of Civilians - An Islamic Perspective', in: M. Cherif Bassiouni \& A. Guellani (red.), Jihad, Challenges to International and Domestic Law, Den Haag 2010, p. 139-166, https://ore.exeter.ac.uk/repository/handle/10036/3417.

53 O. bin Laden, 'Why Are We Fighting You', in: R. Ibrahim (red.), The Al Qaeda Reader, New York 2007, p. 196-208.

54 Lévy 2019, p. 16; L. Blaydes \& L. Rubin, 'Ideological Reorientation and Counterterrorism: Confronting Militant Islam in Egypt', Terrorism and Political Violence 2008-4, p. 461-479, i.h.b. p. 469; L. Rubin, 'Non-kinetic Approaches to Counter-terrorism: A Case Study of Egypt and the Islamic Group', in: L. Rubin, R. Gunaratna \& J.A.R. Jerard (red.), Terrorist Rehabilitation and CounterRadicalisation: New Approaches to Counter-terrorism, Abingdon 2011, p. 26-35, i.h.b. p. 30; C. Green, An Analysis of the Legitimacy and Effectiveness of Salafee Scholarship as an Antidote to Extremism, 2019, http://uir.unisa.ac.za/handle/10500/25993, p. 91.

55 Q. Wiktorowicz, Radical Islam Rising, Muslim Extremism in the West, Lanham 2005, p. 101-105.

56 C.Ch. Fair, J.S. Goldstein \& A Hamza, 'Can Knowledge of Islam Explain Lack of Support for Terrorism? Evidence from Pakistan', 2017 Studies in Conflict \& Terrorism 2017-4, p. 339-355, i.h.b. p. 345 .

57 M. Hasan, 'How Islamic is Islamic State?' New Statesman 10 maart 2015, www.newstatesman.com/world-affairs/2015/03/mehdi-hasan-how-islamic-islamic-state. 
dient voor hen wel als uitlaatklep, zoals Alain Bertho stelt. ${ }^{58}$ De religie is in deze benadering niet de oorzaak van grieven, maar het vehikel met behulp waarvan ze tot uitdrukking worden gebracht.

Die bevinding biedt mogelijkheden voor interventie, te weten het ontwikkelen van een alternatieve uitlaatklep die jongeren kunnen gebruiken voor het uiten van hun woede en idealen. Uit onderzoek blijkt dat er ook andere kanalen zijn die moslimjongeren gebruiken om hun onvrede en ambities tot uitdrukking te brengen, zoals de muziek. ${ }^{59}$ Als zij spontaan voor dit soort minder schadelijke kanalen kiezen, dan kunnen zij daartoe ook door middel van social engineering worden gebracht.

Dit kan worden bereikt met behulp van de receptorbenadering die in de biomedische wetenschap gangbaar is. ${ }^{60}$ Daarmee wordt bevorderd dat een stof de "parkeerplaats' op de membraan van een cel bezet, zodat een kwaadaardige molecuul daar niet meer kan aanmeren en geen schade kan aanrichten binnen die cel. Deze receptorgeneeskunde, waarmee in de praktijk veel medische problemen worden opgelost, neemt dus niet de oorzaak van het probleem weg, maar wel de schadelijke effecten ervan.

Terwijl het onderzoek naar de oorzaken van terroristisch gedrag voortduurt, kunnen de schadelijke gevolgen ervan nu dus al worden weggenomen door de weg naar de gewelddadige islam als uitingsvorm af te sluiten. Het terrorisme kan als uitlaatklep worden vervangen door een positief vehikel, te weten deelname aan de democratische rechtsstaat. Als jongeren meer vertrouwd raken met de theorie en praktijk van het democratisch burgerschap, zullen hun grieven en aspiraties hun weg vinden naar het politieke proces en niet naar het terrorisme, zoals nu soms wel gebeurt. In dat verband is zeer relevant dat de islam zulke actieve maatschappelijke en politieke betrokkenheid bevordert. ${ }^{61}$

Om ervoor te zorgen dat moslimjongeren zich meer eigenaar gaan voelen van de Nederlandse samenleving en haar geschiedenis is het van belang dat zij zich beter bewust worden van de islamitische wortels daarvan. In het politieke en maatschappelijke discours wordt vaak de indruk gewekt dat de islam geen rol van betekenis heeft gespeeld in de Europese en Nederlandse geschiedenis en dat deze pas bij de komst van de 'gastarbeiders' zijn intrede deed. Dit beeld is echter aantoonbaar onjuist. ${ }^{62}$ Islamitische geleerden hebben een vitale rol gespeeld in de Europese kennisontwikkeling doordat ze de klassieke teksten doorgaven, becommentarieerden en verder ontwikkelden. ${ }^{63}$ De aanwezigheid van moslims in Spanje

58 A. Bertho, Les Enfants du Chaos: Essai sur le Temps des Martyrs, Parijs 2016, p. 13.

59 H.D. Aidi, Rebel Music, Race, Empire and the New Muslim Youth Culture, New York 2014.

60 M.F. Roberts \& A.E. Krutchen, Receptor Biology, Weinheim 2016.

61 W. Shahid \& S. van Koningsveld, 'Loyalty to a Non-Muslim Government: An Analysis of Islamic Normative Discussions and of the Views of Some Contemporary Islamicists', in: W.A.R. Shadid \& P.S. van Koningsveld (red.), Political Participation and Identities of Muslims in Non-Muslim States, Kampen 1996, p. 84-114.

62 W.M. Watt, The Influence of Islam on Medieval Europe, Edinburgh 1972; S.E. Al-Djazairi, The Hidden Debt to Islamic Civilization, Londen 2018.

63 D. Gutas, Greek Thought, Arabic Culture, The Graeco-Arabic Translation Movement in Baghdad and Early Abbasid Society (2nd-4th/8th-10th Centuries), Abingdon 1998; V. Moller, The Map of Knowledge: How Classical Ideas Were Lost and Found: A History in Seven Cities, Londen 2019. 
gedurende het Al Andalus-tijdperk, die gepaard ging met uitwisseling van kennis en cultuur, heeft een grote impact gehad op de Europese ontwikkeling. ${ }^{64}$ De jonge Nederlandse Republiek wist haar onafhankelijkheid mede te verzekeren door samenwerking aan te gaan met twee islamitische politieke entiteiten, te weten het Ottomaanse Rijk en de Sultan van Marrakesh, de voorlopers van Turkije en Marokko. ${ }^{65}$ Door de kolonisatie van Indonesië in de periode 1814-1950 was de islam, die een belangrijke rol speelde in de onafhankelijkheidsoorlog, ${ }^{66}$ numeriek zelfs de belangrijkste Nederlandse godsdienst.

De werkloosheid onder moslimjongeren is relatief hoog, en discriminatie op de arbeidsmarkt speelt daarbij een rol. ${ }^{67} \mathrm{Om}$ te verzekeren dat zij een stabiel bestaan in onze samenleving kunnen opbouwen is het belangrijk dat zij over betaald werk kunnen beschikken. Discriminatie op de arbeidsmarkt moet worden teruggedrongen, onder andere door de weerbaarheid daartegen van jonge moslims te vergroten. Daarnaast kunnen zij zich bekwamen in het verwerven van draagvlak op de werkvloer voor de door de islam voorgeschreven geloofspraktijken, zoals kleden, bidden en vasten.

Daarbij kan gebruik worden gemaakt van het concept van 'navigatie en onderhandeling' dat is ontwikkeld door Selby, Barras en Beaman. ${ }^{68}$ In organisaties is de ruimte die men heeft om geloofspraktijken uit te voeren mede afhankelijk van de acceptatie ervan door de organisatiegenoten. Hier gaat het dus niet alleen om het inroepen van rechten, maar ook om het uitleggen en het genereren van draagvlak. Door middel van 'navigatie en onderhandeling' kan men ervoor zorgen dat de ruimte die men krijgt om het geloof te beleven toeneemt zonder de geloofskaart te hoeven spelen, die in een seculiere omgeving überhaupt weinig indruk maakt. Het is bovendien belangrijk dat moslimjongeren die slechts een beperkte kennis hebben van de islam, de gelegenheid krijgen om deze te verdiepen. Op deze wijze worden zij gevaccineerd tegen de vertekende beelden van de islam waarvan terro-

64 D. Levering Lewis, God's Crucible: Islam and the Making of Europe, 570-1215, New York 2008.

65 U. Ryad, "Rather Turkish than Papist": Islam as a Political Force in the Dutch Low Countries in the Early Modern Period', The Muslim World 2017-4, p. 714-736; E. Heinsen-Roach, Consuls and Captives: Dutch-North African Diplomacy in the Early Modern Mediterranean, Rochester 2019.

66 K.W. Fogg, Indonesia's Islamic Revolution, Cambridge 2020.

67 De meeste onderzoeken in dit verband gaan niet uit van de religieuze maar van de etnische achtergrond van de betrokkenen: W. Huijnk, 'Arbeidsmarktpositie en Inkomen', in: W. Huijnk \& I. Andriesen (red.), Integratie in Zicht? De Integratie van Migranten in Nederland op Acht Terreinen Nader Bekeken, Den Haag 2016, p. 77-115; P. Gracia, L. Vázquez-Quesada \& H.G. van der Werfhorst, 'Ethnic Penalties, The Role of Human Capital and Social Origins in Labour Market Outcomes of Second-generation Moroccans and Turks in the Netherlands', Journal of Ethnic and Migration Studies 2016-1, p. 69-87; D. Witteveen \& R. Alba, 'Labour Market Disadvantages of Second-generation Turks and Moroccans in the Netherlands: Before and During the Great Recession', International Migration 2017-2, p. 97-116; M. Ramos, L. Thijssen \& M. Coenders, 'Labour Market Discrimination against Moroccan Minorities in the Netherlands and Spain: a Crossnational and Cross-regional Comparison, Journal of Ethnic and Migration Studies 2019, p. 1-24. De relatie met religie wordt wel direct gelegd in V. di Stasio e.a., 'Muslim by Default or Religious Discrimination? Results from a Cross-national Field Experiment on Hiring Discrimination', Journal of Ethnic and Migration Studies 2019, p. 1-22.

68 J.A. Selby, A. Barras \& L.G. Beaman, Beyond Accommodation: Everyday Narratives of Muslim Canadians, Vancouver 2018. 
ristische organisaties en hun ronselaars zich bedienen. ${ }^{69}$ Op openbare scholen wordt facultatief islamitisch godsdienstig vormingsonderwijs verzorgd. Ouders kunnen het schoolbestuur verzoeken om dit onderwijs aan te bieden, maar van die mogelijkheid wordt nog niet op grote schaal gebruikgemaakt. Gelet op het belang dat de samenleving erbij heeft dat kinderen uit moslimgezinnen een goede ondergrond in de islam krijgen, dient dit type onderwijs zeer actief te worden bevorderd en gefaciliteerd

\subsection{Versterking van de concurrentiekracht van islamitische organisaties}

Een goede manier om de rekrutering van jongeren door terroristische organisaties terug te dringen is te zorgen dat deze organisaties meer concurrentie krijgen. Als bestaande organisaties zich responsiever opstellen ten opzichte van jongeren, zullen dezen minder snel kiezen voor het militante jihadisme. Bovendien zullen terroristische organisaties door deze 'ideologische concurrentie' worden geconfronteerd met hogere kosten. ${ }^{70}$ Op een drukker bezette ideologische markt zullen zij meer middelen moeten spenderen om rekruten aan te trekken, waardoor er minder middelen overblijven om gewelddaden te begaan. ${ }^{71}$

Organisaties als IS en Al Qaida oefenen een grote aantrekkingskracht uit op jongeren omdat zij hoog entitatief zijn. Dat wil zeggen dat zij staan voor duidelijke grenzen, interne homogeniteit, sociale interactie, een duidelijke interne structuur, gemeenschappelijke doelstellingen en een gezamenlijke lotsbestemming. ${ }^{72}$ Ook andere religieuze organisaties, zoals moskeeën, gelden als hoog entitatief en kunnen terroristische organisaties daarom proactief concurrentie bieden. Om dat doel te bereiken zou in de competenties van moskeebestuurders en imams dienen te worden geïnvesteerd. Op die manier kan de verbinding met de jongeren worden behouden, versterkt en zo nodig hersteld.

Verreweg de meeste bestuurders van moskeeën en religieuze verenigingen hebben een migratieachtergrond en profiteren daarom niet van het 'witte privilege. ${ }^{73}$ $\mathrm{Zij}$ hebben daardoor minder gelegenheid gehad om ervaring op te doen met de Nederlandse bestuurs- en verenigingscultuur dan Nederlanders, die deze van generatie op generatie overgedragen hebben gekregen. Het is daarom belangrijk dat bestuurders van moskeeën en religieuze verenigingen de gelegenheid krijgen om beter vertrouwd te raken met de bestuurscultuur binnen de democratie en de rechtsstaat.

69 M.H. Bin Hassan \& K.G. Pereire, 'An Ideological Response to Combating Terrorism - The Singapore Perspective, Small Wars and Insurgencies 2006-4, p. 458-477, i.h.b. p. 466 en 467; de term 'vaccineren' is afkomstig van A.M. Wainscott, 'Defending Islamic Education: War on Terror Discourse and Religious Education in Twenty-first-century Morocco', The Journal of North African Studies 2015-20, p. 635-653.

70 A.Z. Huq, 'Community-Led Counterterrorism', Studies in Conflict \& Terrorism 2017-40, p. 1038-1053, i.h.b. p. 1043-1046.

71 Huq 2017, p. 1043-1044.

72 M.A. Hogg, J.R. Adelman \& R.D. Blagg, 'Religion in the Face of Uncertainty: An UncertaintyIdentity Theory Account of Religiousness', Personality and Social Psychology Review 2010-14, p. $72-83$, i.h.b. p. 74 .

73 K. Bhopal, White Privilege, The Myth of a Post-Racial Society, Bristol 2018. 
Met behulp van professionals kan een aantrekkelijke ICT-omgeving worden opgezet voor moskeeën en verenigingen. Op deze manier zullen jongeren de organisaties voortdurend kunnen bezoeken, ook op momenten waarop deze fysiek gesloten zijn. Door de religieuze content online op een professionele manier aan te bieden en links te verschaffen naar andere relevante sites wordt voorkomen dat jongeren hun informatie elders op het internet gaan opzoeken, inclusief de sites die worden beheerd door militante jihadisten. ${ }^{74}$

Uit onderzoek van Boender blijkt dat de voornaamste taken van imams bestaan uit het voorgaan in gebed en ceremonies, in het doorgeven van basiskennis over de islam en zijn voorschriften en het geven van religieuze adviezen over het geloof. ${ }^{75}$ Tot de taken behoort doorgaans niet het bieden van pastorale zorg, te weten het verlenen van persoonlijke emotionele, sociale en spirituele ondersteuning van de gelovigen. Bovendien toont het onderzoek van Boender aan dat imams ouderen makkelijker bereiken dan jongeren. Jongeren die worstelen met geloofsvragen zouden veel baat hebben bij individuele begeleiding door de imam. In de praktijk blijken geloofsvragen vaak nauw verbonden te zijn met emotionele vraagstukken, die het beste in samenhang kunnen worden opgelost. Daarom is het belangrijk dat de imams in de gelegenheid worden gesteld om hun pastorale competenties te versterken.

Om te zorgen dat jongeren voortdurend in contact kunnen treden met hun geestelijke begeleiders, vooral als zij worstelen met belangrijke geloofsvragen, kunnen door de moskeeën jonge theologen worden aangesteld die de imams assisteren. Deze assistenten, die over pedagogische competenties beschikken, dienen via de telefoon en chatkanalen $24 / 7$ beschikbaar te zijn om eerstelijnshulp te bieden en zo nodig door te verwijzen.

\subsection{De noodzaak om geloofwaardige moslims in te schakelen bij het ontwikkelen van een contranarratief}

Om jongeren af te houden van het terrorisme of hen daaruit los te maken is niet alleen een goede boodschap maar ook een goede boodschapper nodig. Jongeren die gevormd zijn in het militante jihadisme trekken zich doorgaans weinig aan van overheden die zich niet houden aan de sharia en de 'gematigde' moslims die met hen samenwerken. Salafisten daarentegen genieten wel gezag.

Uit onderzoek blijkt dat traditionalistische moslims die zich kritisch opstellen vanwege hun geloofwaardigheid onder jongeren vaak in de beste positie verkeren om militante standpunten te weerleggen. ${ }^{76}$ Onderzoek van Spalek en Zahra McDonald toont aan dat salafistische groepen goed in staat zijn om verbinding te maken met personen die vatbaar zijn voor of al beschikken over militante denkbeelden. ${ }^{77}$ Veel leden van deze salafistische groeperingen beschikken over

74 H. Kesvani, Follow Me, Akhi, The Online World of British Muslims, Londen 2019.

75 W. Boender, Imam in Nederland: Opvattingen over Zijn Religieuze Rol in de Samenleving, Amsterdam 2007, p. 294.

76 Cherney \& Hartley 2017, p. 756.

77 B. Spalek \& L. Zahra McDonald, "Terror Crime Prevention: Constructing Muslim Practices and Beliefs as "Anti-Social" and "Extreme" through CONTEST 2', Social Policy \& Society 2009-9, p. 123-132. 
het nodige krediet, omdat hun achtergronden en ervaringen vergelijkbaar zijn met die van de jongeren. Die straatgeloofwaardigheid komt zeer goed van pas bij het tegengaan van terrorisme. ${ }^{78}$ Om extremisme voor te zijn en aan te pakken zijn juist organisaties nodig die aansluiten bij de waarden van de jongeren die afdwalen. ${ }^{79}$ Ook Green gaat ervan uit dat salafisten de propaganda die wordt verspreid door Al Qaida en vergelijkbare groeperingen, effectief kunnen betwisten. ${ }^{80}$

Hoewel onderzoekers een zeer genuanceerd en veelkleurig beeld schetsen van salafisten in Nederland, ${ }^{81}$ worden zij door overheidsinstanties vanuit radicaliseringperspectief vooral als een veiligheidsrisico beschouwd. ${ }^{82}$ Hun afwijkende manier van kleden en hun neiging om zich afzijdig te houden van de samenleving worden vaak gezien als een opmaat naar een parallelle samenleving, die als een voorportaal wordt beschouwd voor terrorisme..$^{83}$ Maar om te bepalen hoe salafisten zich verhouden tot militante jihadisten zijn deze sociale verschijningsvormen vanuit emisch perspectief veel minder belangrijk dan hun theologische opvattingen. De salafisten en de militante jihadisten beroepen zich beiden op dezelfde bronnen, in het bijzonder het werk van Ibn Taymiyya. Maar salafisten verwijten militante jihadisten in dat verband vaak dat zij geen rekening houden met de context waarin Ibn Taymiyya zijn uitspraken deed en dat zij hem daardoor selectief gebruiken. De methoden en uitkomsten van beide stromingen zijn dan ook zeer verschillend. ${ }^{84}$ Deze verschillen manifesteren zich vooral op het terrein van het gebruik van geweld, de invulling van de jihad en de toepassing van takfir. ${ }^{85}$ Van groot belang is dat salafisten de oproepen tot en de uitoefening van extreem geweld door militante jihadisten afwijzen. Volgens de salafisten vormt zulke vijandige propaganda een ondermijning van de islam, omdat de sharia juist uitgaat van de bescherming van het menselijk leven. Onschuldige personen mogen dan ook niet het slachtoffer worden van gewelddadige aanvallen. ${ }^{86}$ De salafisten ver-

81 De Koning 2008; Roex 2013; M. de Koning, J. Wagemakers \& C. Becker, Salafisme, Almere 2014; M. Berger, M. Kahmann \& S. El Baroudi, Salafisme in Nederland Belicht: Vijftien Jaar Salafisme Onderzoek in Nederland, Utrecht 2018.

82 AIVD, Saoedische Invloeden in Nederland. Verbanden tussen Salafistische Missie, Radicaliseringsprocessen en Islamitisch Terrorisme, Den Haag 2004, www.aivd.nl/documenten/publicaties/ 2004/06/09/rapport-saoedische-invloeden-in-nederland; AIVD, De Gewelddadige Jihad in Nederland: Actuele Trends in de Islamitisch-Terroristische Dreiging, Den Haag 2006. Zie ook het openbaar verhoor van toenmalig directeur-generaal van de AIVD Dick Schoof door de Parlementaire Ondervragingscommissie Ongewenste Beïnvloeding uit Onvrije Landen op 10 februari 2020, www.youtube.com/watch?v=2N1QYXGLYFE; N. Fadil \& M. de Koning, "Turning "Radicalization" into Science: Ambivalent Translations into the Dutch (Speaking) Academic Field', in N. Fadil, M. de Koning \& F. Regazzi (red.), Radicalization in Belgium and The Netherlands: Critical Perspectives on Violence and Security, Bloomsbury 2019, p. 53-79.

83 L. Lindekilde, 'Neo-liberal Governing of "Radicals": Danish Radicalization Prevention Policies and Potential Iatrogenic Effects', IJCV 2012-1, p. 109-125, i.h.b. p. 112-113.

84 Green 2019, p. 67-68.

85 Green 2019, p. 80.

86 Green 2019, p. 81-83. 
werpen ook de opvatting van de militante jihadisten over de jihad. Volgens de salafisten is de jihad erop gericht om de moslimgemeenschap en de samenlevingen waarvan zij deel uitmaakt op vreedzame wijze tot God te brengen. De salafisten zijn van mening dat deze jihad niet met het zwaard moet worden gevoerd, maar door het verwerven van kennis: men moet studeren om te komen tot een correcte belijdenis van het geloof. Anders dan de militante jihadisten beschouwen salafisten het acceptabel om goede relaties te onderhouden met niet-moslims. ${ }^{87}$ Ondanks deze verschillen beschouwen militante jihadisten het salafisme toch als de meest verwante stroming binnen de islam. Tijdens hun religieuze queeste vergelijken militante jihadisten hun standpunten vaak met die van de salafisten. Daarbij komt dan al snel de vraag op wat het salafisme op andere fronten te bieden heeft. Op die manier vindt soms een overgang van het militante jihadisme naar het salafisme plaats. Om die reden kan het salafisme juist ook aantrekkingskracht uitoefenen op aanhangers van het militante jihadisme en hen daaruit een uitweg bieden.

Zo heeft Muhanna-Matar laten zien dat militante jihadisten zich in een proces van zelf-deradicalisering soms tot het salafisme bekeren en geweld afzweren. ${ }^{88}$ Het is dan ook niet verwonderlijk dat de leiders van het militante jihadisme het salafisme als hun belangrijkste concurrent zien. ${ }^{89}$ Als jongeren spontaan kunnen overstappen van het militante jihadisme naar het salafisme, dan kan daarop zelfs bewust worden gestuurd. Op deze manier kunnen salafistische organisaties als brandscherm tegen extremisme dienen in plaats van als een lopende band daarnaar toe. ${ }^{90}$ Daarom verkeren salafisten in de beste positie om een alternatief narratief te verspreiden dat bij de militante jihadisten gehoor zal vinden. ${ }^{91}$

Illustratief in dit verband is de staat van dienst van de salafistische Brixton Mosque in Londen. ${ }^{92}$ Tussen 1990 en 2010 voerde de moskee een succesvolle permanente campagne om jongeren af te houden en los te weken van de Londense tak van Al Qaida. De inzet was gericht op empowerment van deze jongeren. Deze campagne verwierf na verloop van tijd de steun van de Muslim Contact Unit van de Metropolitan Police. ${ }^{93}$ Het negatieve beeld dat buitenstaanders van de Brixton

88 A. Muhanna-Matar, 'The Limit-Experience and Self-deradicalisation: the Example of Radical Salafi Youth in Tunesia', Critical Studies on Terrorism 2017-3, p. 453-475, i.h.b. p. 453.

89 B. Lia, “Destructive Doctrinarians": Abu Mus'ab al Suri's Critique of the Salafis in the Jihadi Current', in: R. Meijer (red), Global Salafism: Islam's New Religious Movement, Londen 2009, p. 281-300.

90 Deze terminologie is ontleend aan Huq 2017, p. 1044.

91 K. Hummel \& M. Logvinov, 'Gefährliche Nähe zwischen Salafismus und Dschihadismus als Sozialer Fakt und Sicherheitspolitisches Artefakt', in: K. Hummel \& M. Logvinov (red.), Gefährliche Nähe, Salafismus und Dschihadismus in Deutschland, New York 2014, p. 11; S. Harris-Hogan, K. Barrelle \& A. Zimmerman, 'What is Countering Violent Extremism? Exploring CVE Policy and Practice in Australia', Behavioral Sciences of Terrorism and Political Aggression 2015, p. 1-19, i.h.b. p. 8 en $9-10$.

92 A. Haqq Baker, Extremists in our Midst, Confronting Terror, Houndmills 2011.

93 R. Lambert, 'Empowering Salafis and Islamists Against Al-Qaeda: A London Counterterrorism Case Study', Political Science \& Politics 2008-1, p. 31-35; R. Lambert, Countering Al-Qaeda in London, Police and Muslims in Partnership, New York 2013. 
Mosque hadden, namelijk dat deze salafistische moskee een gevaar was voor de democratie en dus één pot nat met Al Qaida, moest hierdoor worden bijgesteld.

Gelet op het vorenstaande zou de overheid juist verbinding moeten zoeken met groepen die haar kunnen bijstaan bij het bestrijden van terrorisme. Wanneer zij deze groepen op afstand houdt of van zichzelf vervreemdt, wordt de kip met de gouden eieren geslacht. Daarom is een pragmatische, op resultaat gerichte benadering nodig die ook het samenwerken met salafistische organisaties omvat. ${ }^{94}$ In salafistische kringen bestaat daartoe ook de bereidheid. ${ }^{95}$ Salafistische islamgeleerden zouden kunnen worden betrokken bij het opstellen van een Nederlandstalig contranarratief waarin de stellingen van de aanhangers van het militante jihadisme met behulp van theologische argumenten worden weerlegd. Op die manier worden over de leerstellingen van de militante jihadisten theologische debatten gevoerd, zodat de zwakke plekken daarin kunnen worden aangetoond. In dat verband is van belang dat de theoretici van het militante salafisme hun benadering zo veel mogelijk proberen terug te voeren op bronnen en tradities. ${ }^{96}$ Dat maakt het mogelijk om hun standpunten met behulp van de islamitische theologie te betwisten.

\section{De correctieve benadering: de islam als middel om geweld af te zweren}

In Europa wordt met behulp van deradicaliseringsprogramma's getracht om gedetineerden die zich schuldig hebben gemaakt aan terroristische misdrijven te resocialiseren. Daarbij ligt de nadruk op het omturnen van plegers van terroristische daden tot 'modelburgers' die liberale waarden omarmen. ${ }^{97}$ Deze benadering lijkt geïnspireerd door de opvatting dat de islam een gewelddadig karakter heeft dat alleen kan worden weggenomen als deze godsdienst wordt ingebed in het liberale modernisme.

Hoewel de plegers van terroristische delicten zich ter rechtvaardiging daarvan op de islam beroepen, besteden de Europese deradicaliseringsprogramma's doorgaans geen aandacht aan theologie. ${ }^{98} \mathrm{Zij}$ zetten in op economische en psychologische ondersteuning, maar bieden geen islamologische begeleiding. Voor dit manco worden diverse rechtvaardigingen aangevoerd, zoals de vrijheid van godsdienst, de scheiding van kerk en staat en het ontbreken van relevante expertise. ${ }^{99}$ Het lijkt erop dat de toenemende secularisatie het onmogelijk maakt om de religieuze dimensie in het kader van deradicaliseringsbeleid te adresseren. ${ }^{100}$

94 Lambert 2013.

95 J. Ahajjaj, Radicalisering in Beeld: Een Ontmoeting tussen de Islamitische en Westerse Visie, Den Haag 2015.

96 Maher 2016, p. 17; S.W. Fuchs, Proper Signposts for the Camp, The Reception of Classical Authorities in the Ğihādì Manual al-'Umda fì I'dād al-'Udda, Würzbürg 2011.

97 M.S. Elshimi, De-radicalisation in the UK Prevent Strategy, Security, Identity and Religion, Abingdon 2017, p. 64-65; Lindekilde 2012, p. 110-111.

98 Koehler 2017, p. 83, 118 en 201-207.

99 Koehler 2017.

100 D. Hellmuth, 'Countering Jihadi Terrorists and Radicals the French Way', Studies in Conflict \& Terrorism 2015-9, p. 979-997, i.h.b. p. 987-988. 
Daartegenover staan de rehabilitatieprogramma's die in het Midden-Oosten en Zuidoost-Azië zijn ontwikkeld, die voorzien in het corrigeren van de onjuiste visie op de islam van de betrokkenen. ${ }^{101}$ De programma's gaan ervan uit dat jongeren door middel van indoctrinatie tot terrorisme zijn aangezet. Daarbij is hen door middel van een selectieve interpretatie ten onrechte de gedachte bijgebracht dat de islam het plegen van geweld in veel gevallen toestaat. De kern van de rehabilitatiebenadering is dat militante jihadisten weer op het rechte pad worden gebracht door te leren. ${ }^{102}$ Daarbij zijn alle inspanningen erop gericht dat zij geweld afzweren, terwijl hun andere opvattingen ongemoeid worden gelaten. ${ }^{103}$

In het kader van de rehabilitatie worden de gewelddadige opvattingen en ideeën van de jongeren ter discussie gesteld. Daartoe worden zij tijdens hun detentie enkele uren per dag individueel begeleid door islamitische geleerden, die ook een psychologische training hebben gekregen. Zij wijzen de jongeren op de verkeerde theologische interpretatie die militante jihadisten er van de islam op na houden en brengen hen weer terug op het juiste pad. Jongeren die goede vooruitgang tonen, worden onder beperkingen in vrijheid gesteld, waarna de religieuze coaching wordt voortgezet. Ook de naaste familieleden, in het bijzonder de echtgenoten, worden bij dergelijke activiteiten betrokken.

Rehabilitatie kent niet alleen een spirituele, maar ook een materiële dimensie. Omdat de gedetineerden vaak de broodwinner zijn, krijgen hun gezinnen financiële ondersteuning. Er wordt vooral voor gezorgd dat de kinderen goed onderwijs krijgen om te voorkomen dat ze zich op jonge leeftijd aangetrokken voelen tot het militante jihadisme. De gedetineerden zelf krijgen actieve steun bij hun re-integratie in de samenleving, onder andere door het vinden van werk. ${ }^{104}$

Het door Singapore ontwikkelde rehabilitatieprogramma wordt over het algemeen als zeer succesvol beschouwd. ${ }^{105}$ Omdat het bij rehabilitatie gaat om het ontzenuwen van verkeerde interpretaties van de islam heeft de regering van

101 Zie het Rome Memorandum on Good Practices for Rehabilitation and Reintegration of Violent Extremist Offenders, www.thegctf.org/documents/10162/19594/Rome+Memorandum+on+Good +Practices+for+Rehabilitation+and+Reintegration+of+Violent+Extremist+Offenders.

102 R. Gunaratna \& M. Bin Ali, 'Introduction', in: R. Gunaratna \& M. Bin Ali (red.), Terrorist Rehabilitation, A New Frontier in Counter-terrorism, Londen 2015, p. xv-xxiii.

103 O. Ashour, The De-Radicalisation of Jihadists, Transforming Armed Jihadist Movements, Abingdon 2010, p. 6.

104 K. Ramakrishna, "The "Three Rings" of Terrorist Rehabilitation and Counter-Ideological Work in Singapore, A Decade On', in: A. Silke (red.), Prisons, Terrorism and Extremism: Critical Issues in Management, Radicalisation and Reform, Abbingdon 2014, p. 197-213.

105 A. Rabasa e.a., Deradicalizing Islamist Extremists, Santa Monica: RAND 2000, p. 103; zie voor analyses van het programma H. Weiying, 'The Process of Change in the Rehabilitation of Violent Extremists - the Singapore Experience', in: R. Gunaratna \& S. Hussin (red.), International Case Studies of Terrorist Rehabilitation, Londen 2018, p. 171-179; S.M. Hussein, 'Rehabilitation Journey, The Singapore Experience', in: M.M. Aslam \& R. Gunaratna (red.), Terrorist Rehabilitation and Community Engagement in Malaysia and South East Asia, Londen 2019, p. 121-130; R. Gunaratna \& M.F. Bin Mohamed Hassan, 'Terrorism Rehabilitation, The Singapore Experience', in: L. Rubin, R. Gunaratna \& J.A.R. Jerard (red.), Terrorist Rehabilitation and Counter-Radicalisation: New Approaches to Counter-terrorism, Abingdon 2011, p. 36-58; M.H. Hassan \& T.R. Mostarom, A Decade of Combating Radical Ideology, Learning from the Singapore Experience (2001-2011), Singapore 2011. 
Singapore het primaat gelegd bij de moslimgemeenschap. ${ }^{106} \mathrm{Er}$ is in dit kader een belangrijke rol weggelegd voor islamitische geleerden, omdat die worden geacht over het begrip, de kennis en het gezag te beschikken om de misvattingen over de islam, waarvan terroristen uitgaan, te corrigeren. $\mathrm{Zij}$ hebben op verzoek van de overheid programma's ontwikkeld om jongeren die van het juiste pad zijn afgedwaald weer op de goede koers te brengen.

De praktijk van Singapore werd door het kabinet-Balkende IV als een inspirerend voorbeeld beschouwd. Minister van Binnenlandse Zaken en Koninkrijksrelaties Guusje ter Horst bracht in het najaar van 2008 een bezoek aan Singapore om kennis te maken met het rehabilitatieprogramma dat daar wordt toegepast. $\mathrm{Zij}$ was daarover enthousiast en nodigde vervolgens degenen die verantwoordelijk waren voor het programma uit om daarover in Nederland voorlichting te komen geven. ${ }^{107}$ Op grond van deze positieve indrukken besloot ze te gaan onderzoeken of een dergelijk programma ook in Nederland zou kunnen worden opgezet. Door de val van het kabinet in februari 2010 kon aan dit voornemen destijds geen uitvoering worden gegeven.

\section{Een aanbeveling: de uitvoering van een pilot}

Door middel van een pilot kan worden getoetst of een aanpak gebaseerd op de islam met behulp van de moslimgemeenschap kan bijdragen aan de voorkoming en bestrijding van terrorisme. Deze pilot zou in het kader van gemeenschap-engagerend onderzoek samen met de moslimgemeenschap moeten worden uitgevoerd.

Als onderdeel van de pilot kan een cursus worden ontwikkeld om jonge moslims inzicht te verschaffen in de mogelijkheden om hun frustraties en ambities te articuleren via de democratische rechtsstaat en hen uit te rusten met de benodigde vaardigheden. Die cursus zou erop gericht moeten zijn de deelnemers het gevoel te geven dat zij deelgenoot zijn van de Europese en Nederlandse geschiedenis, hun democratisch-rechtsstatelijke competenties te ontwikkelen, en hen in staat te stellen actief weerstand te bieden aan uitsluiting, discriminatie en racisme.

Met behulp van de deelnemers aan deze cursus kan een 'Canon van de islamitische invloeden op de Europese en Nederlandse beschaving' worden opgesteld. Bovendien kan een training worden aangeboden die moslimjongeren effectiever toeleidt naar de arbeidsmarkt. Daarnaast kan een cursus worden ontwikkeld over de grondslagen van de islam die wordt aangeboden aan jongeren die slechts een oppervlakkige kennis hebben van deze godsdienst, en die belangstelling hebben om die kennis te verdiepen. Tevens kan deelname van kinderen uit moslimgezinnen aan het islamitisch godsdienstig vormingsonderwijs zeer actief worden

106 M. Ali, 'The Religious Rehabilitation Group (RRG): A Community-Government Partnership in Fighting Terrorism', in: Z.A. Rasheed \& N. Saat (red.), Majulah! 50 Years of Malay/Muslim Community in Singapore, Singapore 2016, p. 243-254.

107 Kamerstukken II 2008/09, 29754, nr. 147, p. 13-14; Kamerstukken II 2009/10, 29754, nr. 159, p. 18. 
bevorderd en gefaciliteerd. De nadruk kan daarbij dan liggen op het meer bewustmaken van ouders van deze mogelijkheid, het beter equiperen van scholen voor het aanbieden van dit onderwijs en het bevorderen van de beschikbaarheid van voldoende docenten.

Om te zorgen dat terroristische organisaties meer concurrentie zullen krijgen kan in de pilot een leertraject worden opgenomen om de rechtsstatelijke en democratische competenties van bestuurders van moskeeën en religieuze verenigingen te versterken. Bestuurders die vragen hebben op het terrein van regelgeving en bestuur kunnen dan assistentie vragen aan de medewerkers die aan het project verbonden zijn. Die assistentie kan in de vorm van coaching worden geboden: een projectmedewerker kan de bestuurder zelf het probleem laten oplossen, maar daarbij wel over de schouder meekijken en zo nodig gericht advies geven. Vervolgens kan de betrokken bestuurder hierna voortaan zelfstandig vergelijkbare vragen oplossen en zijn bestuurlijke collega's instrueren hoe zij dat eveneens kunnen doen. Dit zal gepaard gaan met het opzetten van een aantrekkelijke ICTomgeving. Daarnaast kan een cursus worden aangeboden om imams te bewerktuigen voor het verrichten van pastorale taken. In het kader van de pilot kan worden geëxperimenteerd met het aanstellen van jonge theologen als assistentimams door de moskeeën om jonge gelovigen adequater te kunnen bedienen.

Salafistische islamgeleerden kunnen worden ingeschakeld om een Nederlandstalig contranarratief op te stellen waarin de stellingen van de aanhangers van het militante jihadisme met behulp van theologische argumenten worden weerlegd. Daarbij kunnen zij gebruikmaken van werken die reeds in het Arabisch zijn verschenen. De publicatie die hieruit voortkomt, kan in boekvorm en via de traditionele en sociale media worden verspreid.

Als onderdeel van de pilot kan een op de Nederlandse situatie toegespitst rehabilitatieprogramma worden ontwikkeld naar het model van Singapore. Singapore leent zich goed voor vergelijking omdat het evenals Nederland een moslimminderheidland is, waar de scheiding van kerk en staat een belangrijk ankerpunt is. Bovendien is Singapore ook een democratie, gebaseerd op periodieke vrije verkiezingen. ${ }^{108}$ Zo'n rehabilitatieprogramma is niet alleen geschikt voor hen die verdacht zijn van of veroordeeld zijn voor terroristische misdrijven, maar ook voor terugkeerders uit jihadistische strijdgebieden die geen geweldsdelicten hebben begaan. De rehabilitatieaanpak die door de VS is ontwikkeld voor grote aantallen militante jihadistische krijgsgevangenen in Irak kan hierbij als inspiratie dienen. ${ }^{109}$

Bij de inrichting en uitvoering van een dergelijke pilot, die volgens Huq moet worden aangemerkt als een vorm van 'door de gemeenschap geleid antiterrorisme', ${ }^{110}$ zou de staat het primaat moeten gunnen aan niet-statelijke

108 Die verkiezingen worden hoe langer hoe competitiever, zie N. Bowie, 'The Changing Face of Singapore Democracy', Asian Times 10 september 2020. Het gaat overigens niet om een liberale maar een communitaristische democratie, waarin het gemeenschappelijk welzijn hoger wordt aangeslagen dan consumptie, individuele behoeftebevrediging en een claimcultuur, zie B.-H. Chua, Communitarian Ideology and Democracy in Singapore, Londen 1995.

109 A. Angell \& R. Gunaratna, Terrorist Rehabilitation, The U.S. Experience in Iraq, Boca Raton 2012.

110 Huq 2017. 
actoren, met name personen en organisaties die lid zijn van hetzelfde sociale netwerk als de potentiële rekruten voor terrorisme. ${ }^{111}$ Vanwege de scheiding van kerk en staat kan de overheid niet rechtstreeks betrokken zijn bij programma's die gericht zijn op religieuze correctie. ${ }^{112}$ Daarnaast moeten overheden de verleiding weerstaan om 'door de gemeenschap geleid antiterrorisme'-projecten te coöpteren, zoals Huq terecht stelt. Een dergelijke bemoeienis zal aan dit soort particuliere initiatieven de doodsteek geven, omdat deze al snel zullen worden opgevat als een poging om inlichtingen te vergaren in plaats van een oprechte partnerschap tussen de staat en moslimgemeenschappen. ${ }^{113}$ Volgens David Schanzer en Joe Eyerman was een belangrijke faalfactor van het Countering Violent Extremism-beleid van de Obama Administration, waarin de bijdrage van moslimorganisaties centraal stond, dat dit overheidsgestuurd was, waardoor er veel wantrouwen was vanuit de moslimgemeenschap. ${ }^{114}$

De begeleidende rol in dit soort door de gemeenschap gesteunde antiterrorismeprojecten kan het beste worden vervuld door een facilitator, zoals Caitlin Ambrozik heeft aangetoond. ${ }^{115}$ Deze kan aan het project bijdragen door kennis, expertise, menskracht en voorzieningen te leveren. De rol van facilitator zou kunnen worden vervuld door een projectteam van wetenschappers dat beschikt over projectervaring en dat goede banden heeft met zowel de moslimgemeenschap als de overheid.

\section{Conclusie}

Hiervoor is toegelicht waarom het terrorisme dat in naam van de islam wordt gepleegd het beste kan worden voorkomen en bestreden door aan de islam en de moslimgemeenschap een hoofdrol toe te kennen. Door uit te gaan van wat de islam in dit verband kan bieden, kan een groot maatschappelijk probleem met behulp van de theologie worden opgelost. Zo'n beleidswijziging zou in meerdere opzichten echter wel een paradigmawisseling inhouden.

Zo zullen onderzoekers en beleidsmakers hun neiging om seculiere oplossingen te bedenken voor problemen met een religieuze dimensie moeten onderdrukken. Militante jihadisten rechtvaardigen het plegen van geweld met een beroep op de islam, en dat beeld kan het beste met behulp van diezelfde islam worden weerlegd. De overheid zal moeten afzien van pogingen om de islam te domesticeren door te sturen op de ontwikkeling van een 'gematigde' of Europese islam, door invloed uit te oefenen op de opleiding van imams en door aanhangers van het militante jihadisme om te vormen tot modelburgers van liberale snit.

113 Huq 2017, p. 1046.

114 D. Schanzer \& J. Eyerman, Engaging with Communities to Prevent Violent Extremism, A Review of the Obama Administration's CVE Initiative, 2019.

115 C. Ambrozik, 'Community Stakeholder Responses to Countering Violent Extremism Locally', Studies in Conflict \& Terrorism 2019-12, p. 1044-1068. 
Daarnaast zal een beroep moeten worden gedaan op salafisten, ondanks het feit dat zij vaak als een veiligheidsrisico worden gezien, omdat zij een waardevolle bijdrage kunnen leveren aan de voorkoming en bestrijding van terrorisme. Niet alleen betwisten zij met kennis van zaken de gewelddadige interpretaties van de islam van militante jihadisten, zij genieten bovendien geloofwaardigheid onder de jongeren die zich tot dat militante jihadisme aangetrokken voelen.

Ten slotte is het van belang dat de overheid niet zelf alle touwtjes in handen neemt, maar juist ruimte biedt aan de kennis en het inzicht van islamgeleerden en de moslimgemeenschap. Een door de moslimgemeenschap geleid antiterrorismeproject doet recht aan de scheiding van kerk en staat en versterkt het probleemeigenaarschap van de gemeenschap en het vertrouwen in het welslagen ervan.

Zo'n paradigmawisseling zal door sommigen wellicht als radicaal en riskant worden beschouwd. Maar diegenen dienen te beseffen dat doorgaan op de huidige weg, vooral waar het gaat om het gebruik van het strafrecht, de samenleving op den duur zal ontwrichten. Het strafrechtelijke instrumentarium heeft een repressief karakter, maar het wordt steeds vaker preventief ingezet en dat knelt. Bovendien is door de inzet op intenties, dadertyperingen, afgeschermde getuigen en infiltranten een 'vijandstrafrecht' ontwikkeld dat de rechtsstaat steeds verder onder druk zet. ${ }^{116}$ Dit vijandstrafrecht wordt vrijwel uitsluitend op moslims toegepast, die daardoor de status van 'verdachte gemeenschap' krijgen. ${ }^{117}$ Dit leidt bij de moslims tot ergernis en vervreemding en bij andere Nederlanders tot wantrouwen jegens de moslims. Op deze wijze dreigt het draaiboek dat terroristische organisaties als Al Qaida en ISIS hebben ontwikkeld bijna tot de letter te worden uitgevoerd. ${ }^{118}$

116 De term 'Feindstrafrecht' is afkomstig van de Duitse rechtstheoreticus en strafrechtgeleerde Günther Jakobs, die dit strafrecht dat gericht is op uitschakeling van de vijand plaatst tegenover het burgerstrafrecht dat gericht is op herstel van de rechtsorde en resocialisatie van de dader. Zie G. Jakobs, Bürgerstrafrecht und Feindstrafrecht', Onlinezeitschrift für Höchstrichterliche Rechtsprechung zum Strafrecht 5 (maart) 2004, www.hrr-strafrecht.de/hrr/archiv/04-03/index.php3? seite=6; Th. Marzahn, Das Feindstrafrecht als Komponente des Präventionsstaats?, Berlijn 2011; G.L. Morguet, Feindstrafrecht - Eine kritische Analyse, Berlijn 200; H. Noorda, 'Law Reform as a Response to Terrorist Threats', New Criminal Law Review 2020-2, p. 271-299.

117 P. Hillyard, Suspect Community, People's Experience of the Prevention of Terrorism Acts in Britain, Londen 1993; Ch. Pantazis \& S. Pemberton, "From the "Old" to the "New" Suspect Community: Examining the Impacts of Recent UK Counter-terrorist Legislation', British Journal of Criminology 2009-5, p. 646-666; M. van Meeteren \& L. van Oostendorp, 'Are Muslims in the Netherlands Constructed as a "Suspect Community"? An Analysis of Dutch Political Discourse on Terrorism in 2004-2015’, Crime, Law and Social Change 2019-71, p. 525-540.

118 G. Kepel \& A. Jardin, Terreur dans l'Hexagone, Genèse du Jihad Français, Parijs 2015, p. 50-57. 